\title{
Under which conditions does religion affect educational outcomes?
}

\author{
Timo Boppart ${ }^{\mathrm{a}, \mathrm{e}}$, Josef Falkinger ${ }^{\mathrm{a}, \mathrm{c}}$, Volker Grossmann ${ }^{\mathrm{b}, \mathrm{d}}$, Ulrich Woitek ${ }^{\mathrm{a}, \mathrm{c}, *}$, Gabriela Wüthrich ${ }^{\mathrm{a}}$ \\ a University of Zurich, Department of Economics, Zürichbergstr. 14, CH-8032 Zürich, Switzerland \\ ${ }^{b}$ University of Fribourg, Department of Economics, Bd. de Pérolles 90, CH-1700 Fribourg, Switzerland \\ c CESifo, Munich, Germany \\ ${ }^{\mathrm{d}}$ Institute for the Study of Labor, Bonn, Germany \\ e IIES, Stockholm University, Sweden
}

\section{A R T I C L E I N F O}

\section{Article history:}

Received 30 April 2012

Available online 12 December 2012

\section{JEL classification:}

H52

I20

010

Keywords:

Catholicism

Human capital

Political attitudes

Public education

Religious denomination

\begin{abstract}
A B S T R A C T
This paper examines under which conditions religious denomination affects public spending on schooling and educational performance. We employ a unique data set which covers, inter alia, information on numerous measures of public school inputs in 169 Swiss districts for the years 1871/72, 1881/82 and 1894/95, marks from pedagogical examinations of conscripts (1875-1903), and results from political referenda to capture conservative or progressive values. Although Catholic districts show on average significantly lower educational performance and spend less on primary schooling than Protestant districts, Catholicism is harmful only in a conservative milieu. We also exploit information on absenteeism of pupils from school to separate provision of schooling from use of schooling.
\end{abstract}

(c) 2012 Elsevier Inc. All rights reserved.

\section{Introduction}

Recent evidence by Becker and Woessmann (2008, 2009, 2010) suggests that Protestant regions had higher literacy rates, higher density of schools, higher primary school enrolment, and a lower gender gap in education than Catholics in 19th century Prussia. Their findings refine the famous hypothesis of Weber (1905), who argued that Protestantism was conducive to economic development. Weber himself emphasized Protestant work ethic and Protestant motivation to accumulate capital. ${ }^{1}$ By contrast, the evidence by Becker and Woessmann points to the role of religious denomination for economic development through its effect on education.

The analysis presented in this paper advances their hypothesis by shifting the focus away from average effects of religious denomination on education toward the interaction of religion with other sociocultural characteristics. We employ historical data

\footnotetext{
* Corresponding author at: University of Zurich, Switzerland and CESifo, Munich, Germany.

E-mail addresses: timo.boppart@econ.uzh.ch (T. Boppart), josef.falkinger@econ.uzh.ch (J. Falkinger), volker.grossmann@unifr.ch (V. Grossmann), ulrich.woitek@econ.uzh.ch (U. Woitek), gabi.wuethrich@econ.uzh.ch (G.Wüthrich).

${ }^{1}$ See Iannaccone (1998, p. 1474 ff.) for a critical review of Weber's original hypothesis. Employing contemporaneous data, Arruñada (2010) finds no indication that individual working hours are related to religious denomination. However, Schaltegger and Torgler (2010) present evidence which suggests that Protestants give higher priority to work when they are more religious and better educated. A new twist is brought in by Doepke and Zilibotti (2008) who examine the evolution of Protestant values in interaction with occupational choice. More broadly, Woodberry (2012) provides evidence for the relationship between religious missions and democracy and argues that Protestants played an important role for modernization in general with support of mass education being one important mechanism.
} 